\title{
Into the Kimberley: the invasion of the Sturt Creek Basin (Kimberley region, Western Australia) and evidence of Aboriginal resistance
}

\author{
Pamela A Smith
}

The extent to which the traditional owners of the upper Sturt Creek basin in the southeast Kimberley region resisted the exploration and colonisation of their country in the late nineteenth century is generally underestimated and seldom referred to in historical records. This paper documents the exploration and colonisation of the region and analyses accounts of frontier conflict recorded in diaries and other historical documents from this period. These documents provide evidence of many incidents which, when viewed together, suggest that the traditional owners resisted colonisation as best they could without guns, and that the colonists perceived themselves as invaders.

The southeast Kimberley was one of the last regions of Australia to be colonised by Europeans. The upper Sturt Creek basin, which occupies much of the southeast Kimberley (Figure 1), was the route used by the first European explorers entering the east Kimberley and a major route used by the first pastoralists entering the Kimberley with herds of cattle from Queensland.

Much of this land was, and is, the traditional country of Nyininy language speakers (a dialect of Jaru). ${ }^{1}$ Explorers and early pastoralists would have passed close to, if not through, several important meeting places of the Nyininy including Sweetwater on the Sturt Creek and Wan.gu (or Wungu) near Old Flora Valley (Tsunoda 1981: xvi, 6-7). This study examines the nature of the interaction between the explorers, the colonising pastoralists and the traditional owners, the Nyininy. It concludes that the Nyininy sustained a level of retaliation against the pastoralists which, although not able to be defined as an organised resistance movement, was all that was possible given the following imbalance inherent in the processes of colonisation:

In the days I speak of the overlander always carried firearms for his own protection: and of course we were armed. It should be added that the blackfellow on the

1. Tsunoda (1981) has been used to define the boundaries of these language groups, but anthropological research has shown that people who identify by language cannot be described as a single land-owing group (pers. comm. K Doohan). That these people are described as speaking one or other of these languages should not be taken to imply that they were also from a single land-owning group. 
whole was never given a chance and the coming of the whites meant the going of the blacks (Durack 1933: 19).

\section{The exploration and invasion of the southeast Kimberley}

The first recorded exploration expedition to the south-east Kimberley was that of the North Australian Exploring Expedition. This expedition was led by Augustus Charles Gregory, the Surveyor General of Queensland, and it was financed by the Colonial Office. The objectives of the expedition were to explore and map the interior of northern Australia and to report on the suitability of the country for pastoralism. Gregory, with 15 men, 50 horses and 100 sheep, set off from the mouth of the Victoria River, Northern Territory, in September 1855.

The expedition spent three months following the Victoria River to its source and charting its many tributaries. They found much of the country to be rugged and lacking good pasture. Whilst exploring the Hooker Creek they identified the headwaters of another river system and established a depot at Depot Creek to allow a small party to explore this new river (Holmes 1963: 44-47). They mapped the entire length of the river

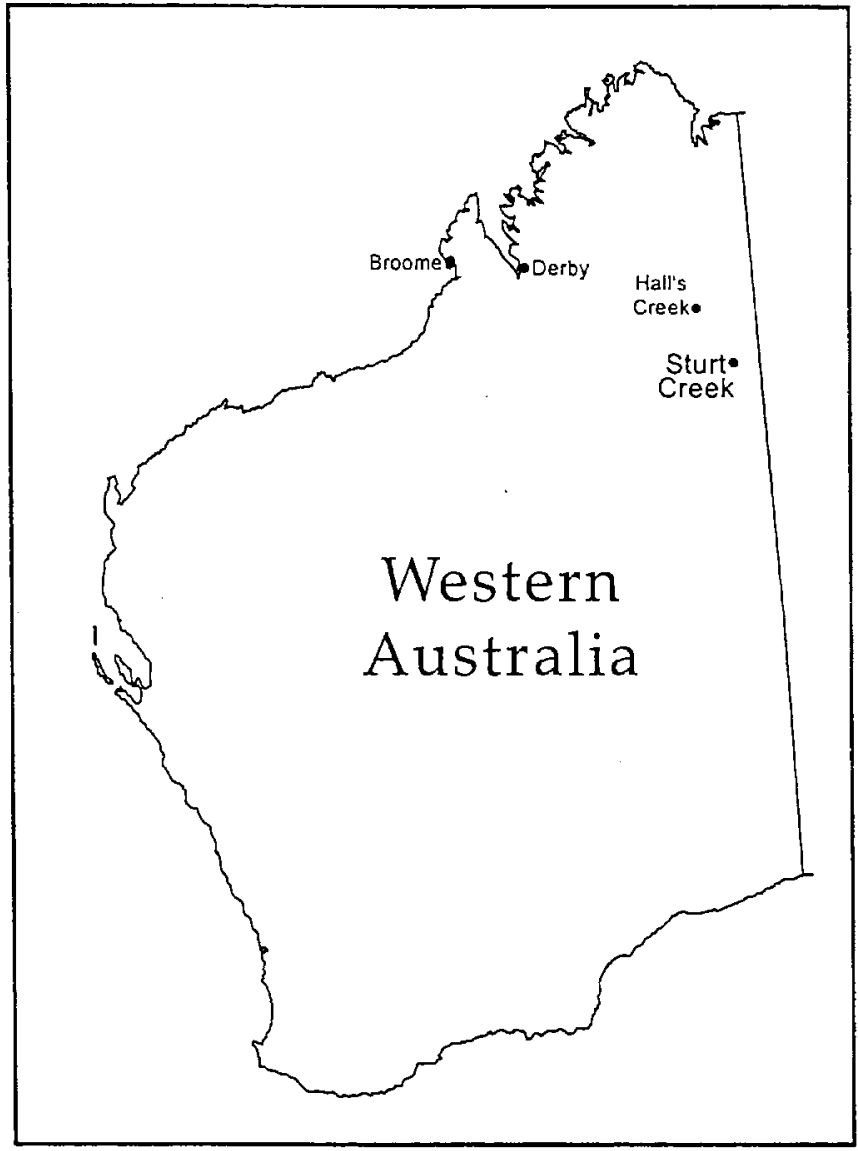

Figure 1. Map of northern Western Australia showing the study area, the upper Sturt Creek basin in the southeast Kimberley region of Western Australia. 
system to where it emptied into a broad, shallow saltwater lake (Lake Gregory, shown on early maps as Gregory's Salt Lake) and named it the Sturt Creek (Figure 2).

On 19 February 1856, Gregory's party passed into the country which was later to become known as Soakage Creek (and later again, as Gordon Downs Station) and on 23 February the Nyininy at Sweetwater saw the first white men to enter their country (Gregory 1884: 134; Tsunoda 1981: 16). Of this country Gregory wrote:

The back country was so nearly level that it scarcely rose above the grassy horizon, while to the south it was so flat that the clumps of bushes looked like islands, the grassy plain extending to the horizon.

Then for two days he lost the creek before coming across pools of brackish water which he again followed and found that 'the channel was gradually lost on a broad swampy flat ... depressed about 10 feet below the grassy plain' which he named the Denison Plain (Gregory 1884: 132).

By 1 March the creek had turned south-southwest and beyond Gregory's Salt Lake the landscape (Gregory 1884: 138) changed to a nearly level plain of red sand, producing nothing but spinifex (Trioda sp.) and stunted bushes, the level of this desert

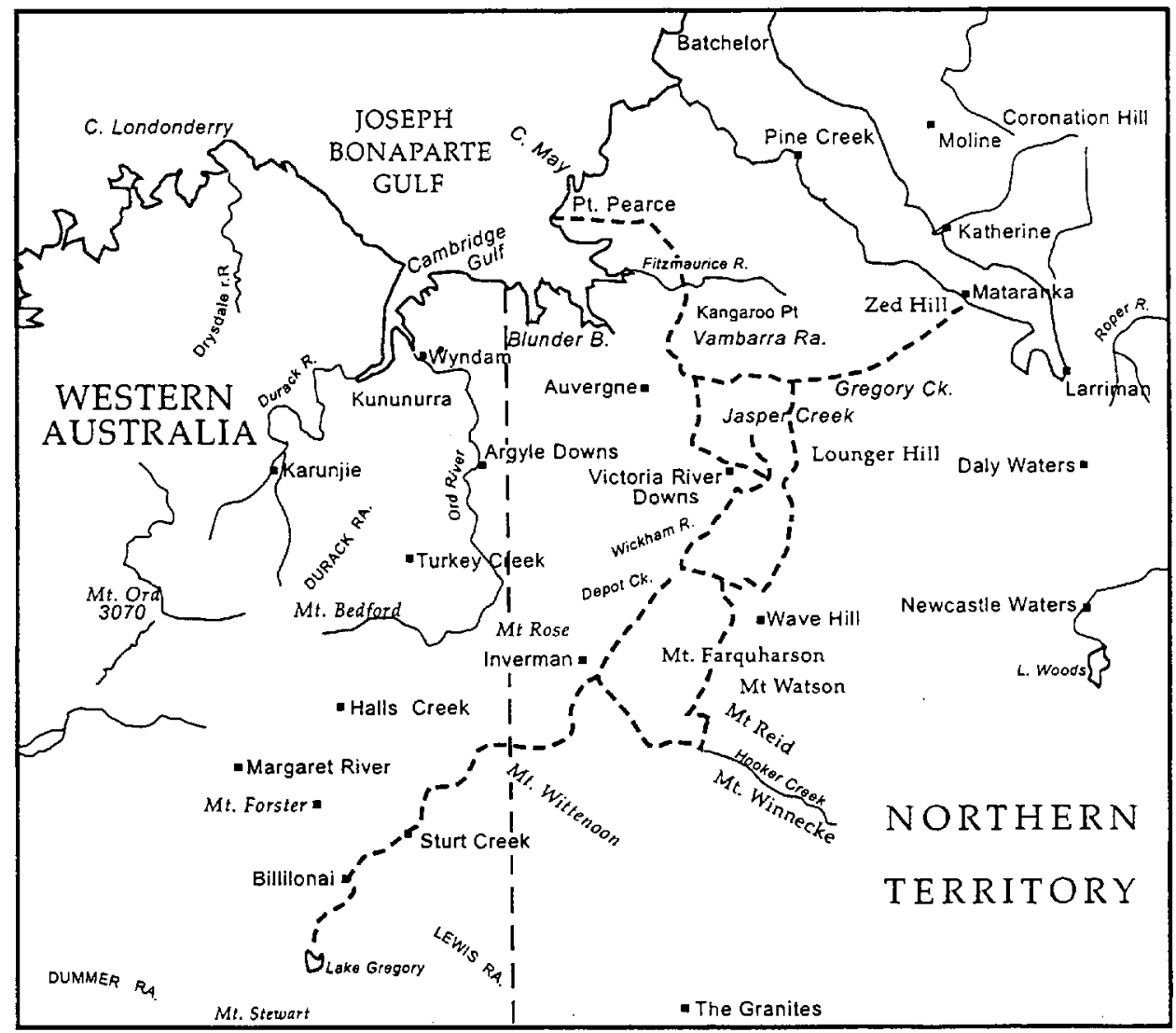

Figure 2. Map of the route taken by the North Australian Exploring Expedition led by AC Gregory in 1855-56 (Cumpston 1972: 132). 
country being only broken by low parallel ridges of drifted sand perfectly straight, and with a direction nearly $E$. and $W$.

Gregory's expedition had entered the Great Sandy Desert to the south of the Sturt Creek basin and had found the unique desert of parallel red sand ridges that extend for thousands of square kilometres to the south and west. They retraced their steps to the depot on the headwaters of the Victoria River to find that there had been a conflict with Aborigines in their absence, the only conflict recorded by the expedition in this region. Despite his reports of good pasture, the Sturt Creek was a series of pools and the reports were not sufficiently favourable to attract colonists. A further 30 years were to elapse before the first colonists arrived.

In 1879-80 Alexander Forrest, a surveyor employed by the Western Australia government, led a well planned and successful expedition to the Kimberley financed by the colonial government of Western Australia. He was the instigator of the expedition and his objective was to report on the suitability of the country for sheep and cattle. From the west coast he crossed the Kimberley and followed the well-watered valleys of the Fitzroy, Ord and Negri Rivers into the Northern Territory. He described one region he passed through as 'the most splendid grassy plain it has ever been my lot to see' (quoted in Bolton 1958: 32). Although he passed north of the Sturt Creek it is likely that he was describing the northern portion of the Denison Plain after a good wet season. In his dispatch to Governor Ord (reported in the Western Australian Times, 23 September 1879) on reaching the overland telegraph in central Australia, he reported:

The chief results of the expedition have been the discovering of the course and source of the Fitzroy and other large streams, together with an area of 20 millions of acres of good well-watered country, suitable for pastoral purposes, besides a large area suitable for the culture of sugar, rice and coffee.

O'Donnell led the last exploring party into the East Kimberley in 1883 on behalf of a group of Victorian investors. Clement documented the several encounters between this party and Aborigines and the varying Aboriginal responses, but none were reported as being overtly hostile (Clement 1987a: 36-40).

Encounters between the explorers and Aborigines were reported as being relatively few and uneventful, although all expeditions recorded that they were aware of being watched and occasionally recorded some contact. Clement, who documented Aboriginal responses to the first Europeans in the Kimberley region, concluded from the available documentary evidence that there was little conflict (Clement 1987a: 6), that few explorers made contact with the Aborigines and that they made no demands on them:

It is likely that East Kimberley Aborigines could have assumed that the Europeans ... who first came to their attention were spirits. In evaluating such situations we should, however, be mindful that each episode of intrusion was unique and that Aborigines consequently had no sets of scope for determining from which world outsiders might have come (Clement 1987a: 25)

There is, however, evidence that the Aboriginal people were concerned by the presence of the explorers. Whilst they did pass rapidly through individual regions and there are few references to direct confrontation, there are the references to being watched and oblique references to Aboriginal attacks. Drawings by a member of Gregory's party, 
provide important evidence of Aboriginal resistance. They illustrate two separate attacks on Gregory's expedition on March 15 and March 24, 1856; a further incident took place on 29 February 1856 (see Cumpston 1972: 80-1).

These illustrations are significant because they demonstrate Aboriginal people 'defending' their country from the time the first explorers entered it. The attacks, however, had little impact on the armed members of the expedition; they occupy only one sentence in Gregory's journal on 28 March 1856 and refer to an incident that had occurred in his absence.

\section{Pastoralists and the 'killing times'}

The overly enthusiastic reports by Alexander Forrest stimulated the immediate settlement of the southeast Kimberley region by pastoralists. In 1881 the government gazetted the Kimberley Land Regulations. By the end of 1882 more than forty-four million acres had been granted to seventy-seven people, and one third of it was leased to five people (Pedersen and Woorunmurra 1995: 23). The epic droving ventures supported by family companies and investment companies began immediately, and between 1882 and 1885 thousands of head of cattle passed through Queensland and the Northern Territory destined for the Kimberley (Buchanan 1933; Buchanan 1997; Durack 1967: 262355). The earliest of these droving expeditions was led by Nat Buchanan in 1883-84. He was already on the McArthur River in the Northern Territory with Panton and Osmand's cattle when O'Donnell was exploring the Ord and Negri Rivers (Buchanan 1997: 89-90; Clement 1987a: 41). Buchanan was soon followed by the Durack brothers, the Emanuels and Charlie and Willie McDonald. They asserted exclusive proprietorial rights to the land, sure that their right to supplant indigenes was justified in the name of progress and sure of their racial superiority (Mulvaney 1985: 68-69). This period is now referred to by the traditional owners of the Sturt Creek basin as the 'killing times' (interview $6^{2}$ ).

Nat Buchanan was the first of the overlanders to have an impact on the study area. He brought 4000 head of cattle from Richmond, Queensland, to Plympton St. Mary (renamed Ord River Station) and arrived on 22 June 1884 (Holmes 1963: 168). This droving expedition has been documented by Buchanan in a history of the family (Buchanan 1997: 89-101). Also in the party were Robert Button (who was to be the first manager of Ord River Station), Buchanan's son Gordon Buchanan, Thomas Cahill and Donald Swan (Bolton 1953; Buchanan 1997: 91). Their employer and holder of the Plympton St Mary pastoral lease was a Melbourne-based company owned by Panton, a Melbourne magistrate, and Osmand, a naval officer ${ }^{3}$ (Lamond 1971: 45).

2. Thirty-three oral histories were recorded as part of this project.

3. Osmand had various investment interests in the Kimberley region and is mentioned by Lamond (1971:45) as being the owner of the Maldon battery close to Melbourne where two tons of stone shipped from the Kimberley was crushed, producing 28 ounces of gold to the ton. Specimens of the gold were put in the window of Brush Drummond's jeweller's store in Collins Street to stimulate interest in a syndicate to invest in the Mt Dockrell gold mine (southwest of Halls Creek). He also owned the Cushie Doo which was anchored off the Cambridge Gulf with a group of Victorian investors at the time Nat Buchanan reached Ord River Station in 1884 (Clement 1987a: 41). 
Buchanan, together with his brothers-in-law Hughie and Wattie Gordon, took a second mob to Wave Hill, an adjacent lease in the Northern Territory. This lease had been taken up by Nat on behalf of the Buchanan family in 1879. The Sturt Creek lease (later named Gordon Downs) was taken up by William Frederick Buchanan, Nat's brother, in 1881 and was stocked with 1800 head of Wave Hill cattle in 1886 (Bolton 1953; Clement and Bridge 1990: 115). By 1888 these pastoral leases, together with Turner, Flora Valley (taken up by Gordon Buchanan in 1887) and Elvire stations (taken up by W.F. Buchanan), formed a continuous family holding of 2222000 acres.

In 1887 the adjacent Denison Downs lease along the south side of the Sturt Creek, owned by $\mathrm{T}$ Foster and Company, was stocked by Stretch, Lewers, Weekes and Foster who brought cattle overland from Normanton, Queensland (Holmes 1963: 168). Denison Downs was later renamed Sturt Creek Station. Figure 3 illustrates the extent of each of these pastoral leases by 1913.

The expansion of the pastoral industry into the southeast Kimberley after 1884 was rapid. The Halls Creek gold rush, which brought 20000 hopeful miners to the east Kimberley by 1886, had ended by 1889 . The ports of Derby (1883) and Wyndham (1886) had rapidly developed to meet the needs of the pastoral and mining industries, with deep water jetties built at Derby (1885) and Wyndham (1894). The Lamboo lease, southwest of Halls Creek, and Billiluna, an extension of the Denison Plains lease, were taken up in 1901 (Holmes 1963: 171). At the same time in the central south Kimberley the Emanuel family was acquiring large pastoral leases which, by 1901, included Lower Liveringa, Noonkanbah, Margaret Downs and Gogo stations on the Fitzroy River and Cherrabun and Christmas Creek Stations on the edge of the Great Sandy Desert (Bolton and Pederson 1980). With the exception of rugged country between Lamboo and Christmas Creek Stations, all of the south Kimberley adjacent to the Great Sandy Desert had been occupied by pastoralists in less than twenty years.

The boom of the 1880s was, however, followed by drought from 1889 to 1892 and the world of the pastoralists was characterised by uncertain weather, loss of stock to spearing by Aborigines, reprisals against the Aborigines by police and pastoralists, and the end of the gold rush. Little changed in the regional economy for a further decade.

Although the explorers had been able to pass through the region with minor conflict, the early period of colonisation, approximately between the mid-1880s and 1920s, was characterised by violence, chaos and the marginalisation of the Aboriginal people from their country. They were confronted with rapid and radical social and economic change. Thousands of head of cattle spread through the fertile river valleys and within a few years the significant life-giving waterholes created and occupied by the spiritual ancestors of the Nyininy/Jaru had been depleted and fouled by cattle. The diversity of vegetation declined rapidly, with many species of native fauna being dispersed to more remote regions and some forced to the brink of extinction (Haynes et al. 1974: 34).

The underlying reasons for the frontier tensions are complex. At the time the Kimberley region was colonised, Indigenous Australians were perceived by influential academics following Darwin as being the primitive forebears of modern humans and early anthropologists of this period viewed Aboriginal society as a social laboratory to test theories of evolution (Mulvaney 1985: 69). This belief is now known as 'Social Darwinism' (Griffiths 1996; Weil 1995). This and the belief that domestic agriculture and pasto- 
ral endeavours were the proper purposes for owning land led the early colonists to view Australia as a wilderness, 'terra nullius', unowned and unaltered by the inferior indigenous people who inhabited it (Jones 1985: 183; Dodson 1991: 14). These beliefs were tenacious and Social Darwinism determined attitudes to Aborigines that endured in Australian government policy until the middle of the twentieth century.

In a history of this period centred round the story of Jandamarra in the West Kimberley, Pedersen and Woorunmurra (1995) demonstrated very clearly that the colonisation of that region was a process of invasion which met with strong resistance. There are few records of this period for the southeast Kimberley, but those that do exist provide evidence of these first encounters and evidence that the pastoralists met with resistance, although spears were never a match for guns.

Guns were the crucial element in the frontier violence. They were used by pastoralists to maim and kill in order to deter Aboriginal people competing with stock for water or passing through their traditional country (interview 3). Tindale, whilst recording at Halls Creek in October 1953, met an old man, Old Moses or Tjulku, a Nyininy speaker. Tindale made the following notes in his journal:

Old Moses (R.1203 Tjulku) who was born before white men came to the country. He said he first encountered white men when he was a child at Marala - now on Nicholson Station - when white men droving bullocks came up and shot at them as soon as they were seen. The same white saw them again at Kardarj. The blacks didn't understand. The whites were 'cheeky' and shot an old man and a young man. Tjulku was a little boy ran away with his mother 'we got away'. His second experience with whites was some time later when Willie Magistrate, who made a cattle station on Sturt Creek shot and killed his elder brother Maltjudu in a 'row over bullock' at Naiwayaiwa Pool on the Sturt Creek (Tindale 1953-4:1075).

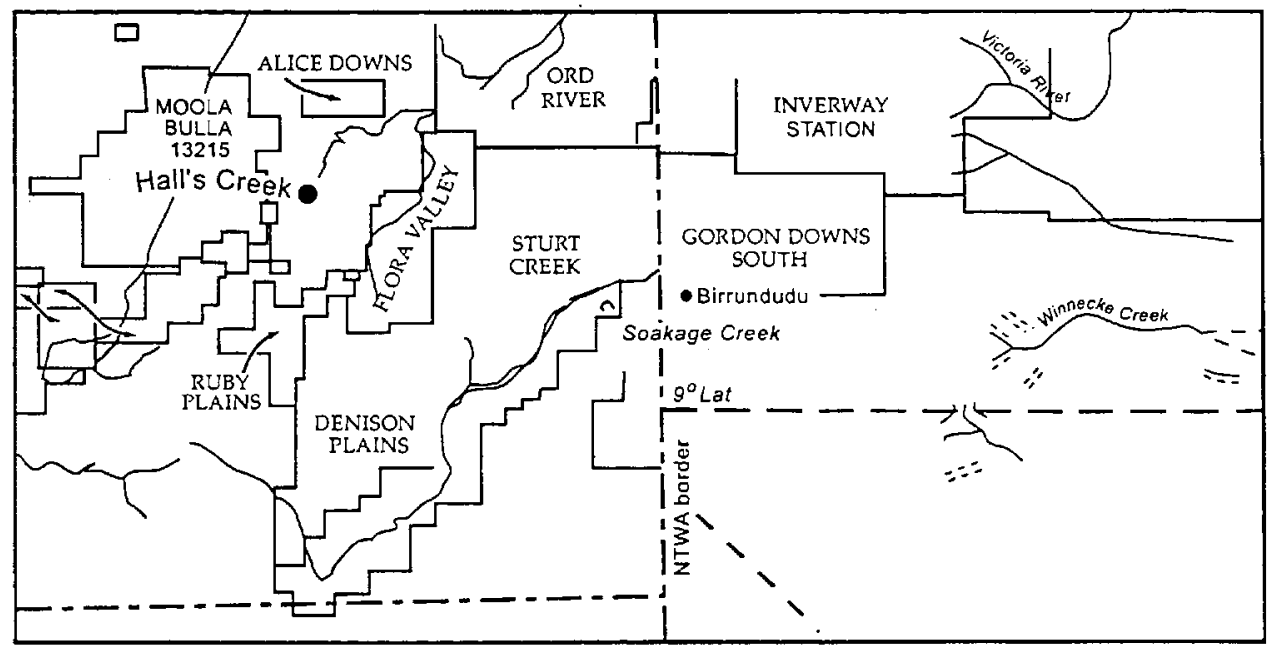

Figure 3. Map of pastoral leases in the study area after 1913, recorded in Clement 1987b:vi from portion of Dept Lands and Surveys locality map Perth, WA. Combined maps from Clement 1987b: vii and map of pastoral leases in the North Territory from about the 1930s (source unknown). Gordon Downs is referred to as Sturt Creek on the WA side of the border; Sturt Creek Station is marked as Denison Downs Station. 
The pastoralists brought cattle and cattle were quickly recognised by Aboriginal people as an easily obtained and desirable source of food. Cattle-spearing became rife, not only for food but as a form of resistance. In a chapter entitled 'The Black Tastes Beef' (Buchanan 1933: 156) the personal experiences of Gordon Buchanan provide a unique and valuable insight into the frontier and into the reasons why cattle were speared.

In 1889 the blacks about Wave Hill, who had become more cunning, if not more hostile under the severity of Sam Croker's regime, were killing and wounding cattle on all sides. They were not long in acquiring both a taste for beef and the knowledge of how best to secure it. Grown cattle were seldom killed outright at the first attack, but ambushed and wounded, were followed and chased for hours until they became an easy prey. As the blacks gained more knowledge, relays of warriors began to be posted along the cattle pads leading from the watering places. Heifers and cows heavy in calf were the first to fall; for this reason the increase in the herds was much retarded ... In this year they became much bolder and made several raids to within a few miles of the head station itself. I was manager at that time. One day while Ferguson, Barry, black boy George and I were riding about ten miles out we encountered a fully armed party of about thirty bucks stalking some cattle near the Red Lily Spring ... a dash was made for the blacks who, splitting into several groups, retired for a short distance and then showed fight (Buchanan 1933: 156-64).

As is usual for such accounts, Buchanan does not say whether or not lives were lost in this encounter. This and other examples in the same chapter argue that the cattle were being speared not only for food, but as a reaction to the severity of a recent manager. $A$ second example illustrates a similar motive:

Once in a raid on Sturt Creek cattle a stray beast from Flora Valley had been inadvertently speared. A Flora Valley boy who happened to be present and noticed the earmark was sent to Flora Valley with an apology from the offending tribe; they were very sorry, so he said, they thought their quarry were cattle 'all belonga Willie' - referring to W.H. Stretch, the owner of Sturt Creek (Buchanan 1933: 202)

In a brief history of the Aboriginal community at Yaruman (Kundat Djaru community close to Gordon Downs Station) Buchanan was described as putting in place

a policy of encouraging local groups to settle on the station property while hunting and killing those still free in the bush. He recorded 'These boundary-riding excursions to protect the white invader and his stock from the dispossessed and naturally retaliatory aboriginal (sic) ... were the most urgent and trying of any work'. Yaruman old people still tell of massacres in the area. The violence of these years was one side of a dual process (Taylor 1988: 39).

The reader is left with no doubt that there must have been many unrecorded killings in this region conducted as part of the process of colonisation and this quote from Buchanan makes it clear that he perceived himself and other pastoralists as the 'white invader' and that he recognised and acknowledged that the Aboriginal owners of the land were both retaliatory and dispossessed (Buchanan 1933: 156-64).

Gee, in his reminiscences as Warden of Goldfields and Special Magistrate, recorded that many of the Aborigines on the Tanami gold fields in the 1920s came from the Sturt Creek region and that they fell into two categories - those who were useful and worked for the miners and those who were myalls (bush Aborigines) and were likely to attack their camps. The latter were regarded as treacherous and were shot. He 
recorded at length the treachery of one cheerful, helpful man who attempted to murder the camp leaders (Gee 1926: 26-31).

The story recounted in Figure 4 and copied from the Kutjungka (Balgo) Parish Newsletter, tells the story of the Sturt Creek massacre, which took place in the later end of 'the killing times', probably in the 1920s. Although the date is uncertain the story is frequently retold and the site of the massacre is well known and continues to be visited (interview 32).

Following this massacre many people from Sturt Creek Station and Gordon Downs Station - both along the Sturt Creek - took refuge at Lewis Creek and Slatey Creek Stations, pastoral leases in marginal desert country to the southeast in the Gardiner Ranges. Tom Bradshaw was at Slatey Creek, Jack Skeen and Dave Piggley were at Lewis Creek and both were married to Aboriginal women. Piggley is reported to have carried a pair of pistols which he used to threaten white men who came looking for Aboriginal people. Some of those interviewed in Halls Creek and Kundat Djaru lived here with their grandparents as children, while many of the young men and women, their parents, had been captured or enticed to work for rations on Sturt Creek and Gordon Downs Stations (Terry 1925: opp. 226; interview 6; pers. comm. K Doohan). They reported that the hills also provided excellent hiding places to which the cattle could be hunted and killed out of sight of the pastoralists.

The price of resistance was, however, most often the loss of life or capture and exile to work in labour gangs in Wyndham. A meeting of pastoralists from the East Kimberley region was held in 1901 to discuss police protection and pastoralists called for 'methods similar to those employed in North Queensland', that is, the wholesale killing of Aborigines on stations (Clement 1987b: 26). Few massacres on Jaru land have been documented, but the Kija people, on the northern boundary of the study area, are known to have lost many lives through several massacres ${ }^{4}$.

The following quote relates to a punitive expedition following the attempted murder of an Aboriginal stockman in the study area in the 1920s; it is most likely that it was members of the Walmajarri and Jaru who were involved. It was recalled by Grant Ngabidj who was working in the Sturt Creek area and who was about sixteen at the time:

Four Halls Creek policemen and three other white men came out. Somebody told them who the two blackfellers were and they went low down looking around among the bush people. They told them, 'Oh big mob there, longa billabong, longa Wolf junction', and they sneaked up. There may have been about twenty or thirty police boys too. They did not tie them up or take them to the jail house; they murdered the whole lot of them, shot them all: Balgo mob, Sturt Creek mob and Billiluna mob; women, piccaninnies, dogs, old people, young people, middlesized people - finished them. I was there when it happened but they did not shoot me because I came from this other way and I was a stockman (Shaw 1981:47)

4. Information from the Kimberley Aboriginal Language Centre. 


\section{MIRLI-MIRLI WANGKALALTUKURLU}

\author{
Kutjungka Parish
}

Weekend March 15/16, 1997

Parish Newsietter, Year 5, No 10, 1997

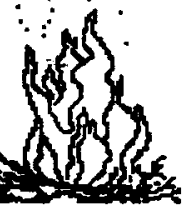

Lent Story Number 4

Clancy and Spleler - Sturt Creok Maseacres

On top of Sturt Creek, the old station on top of the hill. The old people used to spear cattle. Cut 'em up - use a rock. They didn't know white man owned those bullock. Hungry for a feed and the bullock was easy to catch. White man came along and caught them

And that's when kartiya started shooting those people. They want th shoot them like a dog. Shoot them like a bullock. For stealing cattle

They took them to Sturt Creek. Tied them between two big trees, in chain. White blokes started shooting from one end and other end. And they meet up in the middle. Finish. That tree was full of blood.

They get a horse, put a rope along their neck and drag them to the well. Chuck them in - whole lot. Get 'em kerosene. Pour 'em in ano then light 'em. Burn all the black fella in that well atter shooting them

We mob bin kids. We were playing in the water, Sturt Creek Station. Little ones, lamparn-lampam. Me and my brother was there. Watch 'en all them dead fellow. We used to see them dragging 'em those body with a horse. We bin hear 'em shoot 'em till they were finish. Drag them again, two bronco horse. Take them back to the well. Make 'em full again. All them dead bodies bin make that well come right full, kankami. Kankami means right full. When they bin go up. burn them with kerosene. Bin go down again.

Bone - kiji. That white one now. Body. Bone for everyone. Every place, all our families. Light 'em, you can see that smoke. Spirt goinh up, spirt of them dead people. From there you can look all the ashes: and bone. You can see the ashes there now.
Figure 4. Recounting the Sturt Creek Massacre (Kutjungka Parish (1997)).

\section{Discussion}

Historical documents provide only one side of the frontier conflict, the perceptions of the explorers and the colonising pastoralists, and there is no doubt that those referred to above underreported the Aboriginal presence. These documents are embedded in a culture which condoned the oppression and the extermination of Aboriginal people who resisted colonisation as integral to the 'pacification' process.

The diaries of Gregory (Gregory and Gregory 1884) and later, Carnegie (1898), frequently refer to being watched from a distance or note that they had observed smoke on the horizon, an indication that the Aboriginal people always knew where they were and what they were doing. The explorers must have also been aware of the many significant precontact Aboriginal sites in the Sturt Creek basin (see Veth 1980; Smith 2000) and would have known that a significant Aboriginal population lived in the region.

Few written records of the period were maintained by the pastoralists, although we are fortunate that Gordon Buchanan, the son of Nat Buchanan, documented his 
father's life (Buchanan 1933) and that a comprehensive family history has been compiled by Bobby Buchanan (Buchanan 1997). Whilst some records refer to the Aboriginal people as a treacherous people, Gordon Buchanan acknowledged that they were dispossessed and were 'naturally retaliatory' as a result of their dispossession. He also acknowledged that the boundaries of the pastoral leases were protected by shooting those Aborigines not incorporated into the workforce on the station as they competed with cattle for water resources (Buchanan 1933; Taylor 1988: 39; interviews 3, 7, 21) 5 . This he described as being the 'most urgent and trying of any work (Buchanan 1933: 164).

The history of the Aboriginal people in the southeast Kimberley from their own perspective remained undocumented until anthropologists, usually more interested in traditional culture, incidentally recorded memories of the frontier conflict following colonisation (Tindale 1953-54), followed by a later generation of historians and anthropologists concerned to document this period while senior traditional owners were able to be recorded (Shaw 1981; Clement 1987a,b; Smith 2000, and numerous records held by the Kimberley Land Council and the Kimberley Aboriginal Language Resource Centre).

The recording of the contact history of the study area from the perspective of the dominant culture has resulted in a perception that the process of colonisation by pastoralists met with little or no resistance. However, almost all examples of contact described above are able to be interpreted as examples of resistance, although seldom effective and with no apparent long-term benefits to the Aboriginal community. The evidence from recorded oral histories reveals that many of the traditional owners, as individuals and small family-based units, did defend their country as best they were able and that their most effective form of resistance was to spear cattle. They perceived themselves as a threatened people, who knew that their weapons were inferior to guns and who were forced to calculate each small advantage.

The end of the frontier period in this region cannot be defined by a date. It was a gradual transition and the population continued to move between a traditional lifestyle hunting and gathering and the station camps until at least the 1960s (Micha 1961). The process of 'pacification' was, however, almost complete by the late 1920s, with the pastoralists asserting exclusive proprietorial rights to all of the land and water resources.

\section{Acknowledgements}

Oral histories were recorded as part of a wider project and the memories of senior members of the Jaru people have contributed to deeper understandings about the colonisation of this region. The field research for this study was undertaken with the cooperation of senior Aboriginal people living at Kundat Djaru community, several of whom have since passed away. Flinders University, Adelaide, provided both financial support and a supportive academic environment. I also wish to thank those who read and commented on drafts of this paper - they include Donald Pate, Kim Doohan, Daniel Vachon, Joe Blythe and Matthew Wrigley. This paper is based on research undertaken for my PhD thesis (Smith 2000).

5. Smith has documented the conflict between the traditional owners and the pastoralists over water resources in this region (Smith 1999, 2000). 


\section{References}

Bolton, GC, 1953. 'A survey of the Kimberley pastoral industry from 1885 to the present.' Unpublished MA thesis, Dept History, University of Western Australia, Perth.

Bolton, GC, 1958. Alexander Forrest, his life and times. Melbourne.

Bolton, GC and H Pedersen, 1980. 'The Emanuels of Noonkanbah and Gogo.' Early Days: Joumal of the Royal Western Australian Historical Society 8(4): 5-21.

Buchanan, B, 1997.In the tracks of Old Bluey. Rockhampton.

Buchanan, G, 1933. Packhorse and waterhole: with the first overlanders to the Kimberley. Sydney.

Carnegie, DW, 1898. Spinifex and sand. London (reprinted in Penguin Colonial Facsimiles, 1973).

Clement, C, 1987a. Pre-settlement intrusion into the East Kimberley. East Kimberley Impact Assessment Project, Working Paper no. 24, Centre for Resource and Environmental Studies, ANU, Canberra.

Clement, C, 1987b. Historical notes relevant to impact stories of the East Kimberley. East Kimberley Impact Assessment Project, Working Paper no. 29, Centre for Resource and Environmental Studies, ANU, Canberra.

Clement, C and P Bridge (eds), 1990. Kimberley scenes: sagas of Australia's last frontier. Perth.

Cumpston, JHL, 1972. Augustus Gregory and the Inland Sea. Roebuck Society Publication no. 9. Canberra.

Dodson, P, 1991. Royal Commission into Aboriginal deaths in custody. Regional report of enquiry into underlying issues in Western Australia. 2 vols. Canberra.

Durack, M, 1967. Kings in grass castles. Condell Park, NSW.

Durack, PM, 1933. 'Pioneering in the east Kimberley.' Early Days: Joumal of the Royal Historical Society of Western Australia, 2: 2-28.

Gee, LEC, 1926. Bush tracks and gold fields: reminiscences of Australia's 'Back of Beyond'. Adelaide.

Gregory, AC, 1884. Journals of Australian explorations. Brisbane.

Griffiths, T, 1996. Hunters and collectors: the antiquarian imagination in Australia. Melbourne.

Haynes, BT, GEB Barrett, A Brennan and L Brennan, 1974. WA Aborigines 1622-1972. Themes from Western Australian history. Nedlands.

Holmes, JM, 1963. Australia's Open North. Sydney.

Jones, R, 1985. 'Ordering the landscape', in I Donaldson and T Donaldson (eds) Seeing the first Australians. Sydney, pp 181-209.

Kutjungka Parish, 1997. Lent Story no. 4. Clancy and Spieler - Sturt Creek massacres. MirliMirli Wangkalaltukurlu. Parish Newsletter 5(10), March 15-16.

Lamond, WH, 1971. Five years in the Kimberley. Early Days: Journal of the Royal Western Australian Historical Society, 7(3): 27-49. 
Micha, FJ, 1961. Eingeborene als arbeitskrafte auf den viehstationen der sudostlichen Kimberley, vormehmlich auf Gordon Downs station. Herman Trimborn sum 60 . Geburtstag. Braunschweig, pp 65-93.

Mulvaney, DJ, 1985. 'The Darwinian perspective', in I Donaldson and T Donaldson (eds) Seeing the first Australians. Sydney, pp 68-75.

Pedersen, H and B Woorunmurra, 1995. Jandamarra and the Bunuba Resistance. Broome.

Shaw, B, 1981. My country of the Pelican Dreaming: the life of an Australian Aborigine of the Gadjerong, Grant Ngabidj, 1904-1977. Canberra.

Smith, PA, 1999. 'Station camps: identifying the evidence for continuity and change in the south-east Kimberley, WA.' Paper presented to the Australian Association of Archaeologists Conference, Mandurah, Western Australia, December.

Smith, PA, 2000. 'Station camps: the ethnoarchaeology of cultural change in the postinvasion period in the south Kimberley, Western Australia.' Unpublished PhD thesis, Dept Archaeology, Flinders University, South Australia.

Taylor, P, 1988. After 200 years: photographic essays of Aboriginal and Islander Australia today. Canberra.

Terry, M, 1925. Across unknown Australia: a thrilling account of exploration in the Northern Territory of Australia. London.

Tindale, NB, 1953-54. Expedition of University of California, Los Angeles and University of Adelaide 1953-4. Joumals of NB Tindale, Volumes 1-4. Adelaide.

Tsunoda, T, 1981. The Jaru language of Kimberley, Western Australia. Pacific Linguistics Series B no.78, Research School of Pacific Studies, ANU, Canberra.

Western Australian Times 23 September 1879.

Veth, PM, 1980. 'Sturt Creek survey.' Unpublished preliminary field report.

Weil, S, 1995. A cabinet of curiosities: inquiries into museums and their prospects. Washington. 